\title{
ANALISIS PENYELESAIAN KREDIT BERMASALAH PADA BANK BNI 46 CABANG POLEWALI MANDAR
}

\author{
The Analysis of Non Performing Loans at Bank BNI 46 Polewali Mandar Branch \\ Syarief Rahmat Tasman ${ }^{1}$, Zulkifli Makkawaru', Yulia.A.Hasan ${ }^{3}$ \\ ${ }^{1}$ Bank BNI 46 Cabang Polewali Mandar \\ ${ }^{2}$ Program Studi Ilmu Hukum Program Pascasarjana Universitas Bosowa \\ Email: syariefrahmant64@gmail.com \\ Diterima: 10 Januari 2021/Disetujui: 01 Juni 2021
}

\begin{abstract}
ABSTRAK
Tujuan Penelitian ini adalah untuk mengetahui cara penyelesaian kredit bermasalah di Bank BNI 46 Cabang Polewali Mandar. Metode yang digunakan untuk penelitian ini adalah metode deskriptif yaitu dengan menguraikan data secara sistematis dari fakta-fakta yang didapat kemudian dihubungkan dengan prosedur penyelesaian kredit bermasalah pada Bank BNI 46 Cabang Polewali Mandar. Terjadinya Kredit bermasalah di Bank BNI 46 disebabkan oleh faktor intern yaitu pejabat kredit mudah dipengaruhi atau dipaksa oleh calon nasabah, kurangnya pemahaman terhadap kebutuhan keuangan yang sebenarnya dari calon nasabah dan manfaat kredit yang diberikan seperti kredit modal kerja digunakan untuk komsumtif, kurangnya pengecekan latar belakang calon nasabah dan juga disebabkan oleh faktor ektern yaitu karena merosotnya perekonomian debitur, terjadinya PHK mendadak ditempat kerja debitur, penurunan omset usaha debitur, dan Upaya penyelesaian Kredit bermasalah yang disebabkan oleh Faktor Intern dilakukan dengan peringatan tertulis dalam bentuk Surat Peringatan (SP), mutasi dan penurunan jabatan, serta upaya penyelesaian Kredit bermasalah yang disebabkan oleh faktor ekstern dilakukan dengan mengirim Surat Peringatan SP I sampai SP 3 melakukan penangihan kepada pihak yang ikut serta menandatangani perjanjian kredit dan terakhir melakukan penarikan dan pelelangan agunan.
\end{abstract}

Kata Kunci : Kredit Bermasalah, Pengawasan, Penyelesaian, Keadilan

\section{ABSTRACT}

The purpose of this study was to determine what to find out how to solve problem loans at Bank BNI 46 Polewali Mandar Branch. The data analysis method for this research is descriptive method, namely by describing the data systematically from the facts which can then be linked to the procedure for solving problem loans at Bank BNI 46 Polewali Mandar Branch. The occurrence of non-performing loans at Bank BNI 46 is caused by internal factors, namely credit officials who are easily influenced or forced by prospective customers, a lack of understanding of the actual financial needs of the prospective customer and the benefits of loans such as working capital loans used for commercial use, lack of background checks on candidates customers and also caused by external factors, namely due to the decline in the debtor's economy, sudden layoffs at the debtor's workplace, a decrease in the debtor's business onset, and efforts to resolve problem loans caused by Internal Factors are carried out with written warnings in the form of Warning Letters (SP), mutations and decreases position, as well as efforts to resolve non-performing loans caused by external factors are carried out by sending a warning letter from SP I to SP 3 for invoicing the parties participating in signing the credit agreement and finally making a withdrawal and auction of collateral.

Keywords: Non-Performing Credit, Supervision, Settlement, Justice

\section{PENDAHULUAN}

Bank merupakan lembaga keuangan yang berorientasi pada bisnis yang mempunyai kegiatan pokok untuk membeli uang dengan cara menghimpun dana dari masyarakat dan kemudian menjualnya kembali kepada masyarakat melalui pemberian kredit atau pinjaman. Dari kegiatan jual beli inilah bank dapat memperoleh keuntungan yaitu selisih harga beli (bunga simpanan) dengan harga jual (bunga pinjaman).

Sebagaimana diketahui bahwa bank mempunyai peranan sebagai perantara pihak berkelebihan dana dan kekurangan dana yang usaha pokoknya adalah memberikan kredit dan jasa-jasa dalam pembayaran dan peredaran uang. Kredit yang dikeluarkan oleh bank dapat digolongkan berbagai macam, baik menurut sifat penggunaan, jangka waktu pemakaian, keperluan kredit maupun jaminan kredit.

Kegiatan menyalurkan kredit mengandung risiko yang dapat mempengaruhi kesehatan dan kelangsungan usaha Bank. Likuiditas keuangan, solvabilitas dan profitabilitas Bank sangat dipengaruhi oleh Keberhasilan mereka dalam mengelola kredit yang disalurkan. Dalam memberikan 
kreditnya kepada para nasabah tersebut berkenaan dengan keyakinan atas kemampuan dan kesanggupan debitur untuk melunasi hutangnya dikemudian hari, bank harus melakukan penilaian yang seksama terhadap watak, kemampuan, modal, agunan dan prospek usaha yang dimiliki oleh debitur.

Dalam pemberian kredit, selisih rugi terjadi jika pelaksanaan tidak sesuai dengan rencana yang ditetapkan, dapat berupa angsuran tidak sesuai dengan perjanjian kredit, nasabah tidak dapat melunasi pinjamannya dalam waktu yang disepakati, kredit tidak digunakan sesuai dengan tujuan permohonan kredit dan sebagainya. Kondisi ini umumnya disebut dengan kredit bermasalah.

Proses analisi terhadap kredit bermasalah pada Bank BNI 46 Cabang Polewali Mandar akan lebih sulit jika dibandingkan dengan melakukan analisis pada kredit baru. Hal ini bisa diibaratkan dengan "membangun rumah," akan lebih mudah membangun rumah baru di tanah kosong dan pada menata kembali rumah yang sudah rusak. Lebih lanjut dapat disebutkan memperbaiki performance kredit bermasalah lebih sulit dibandingkan dengan memberikan kredit baru. Oleh karena itu, bank BNI 46 Cabang Polewali Mandar harus senantiasa menerapkan prinsip kehati-hatian dalam penyaluran kredit, disamping itu bank BNI 46 juga harus senatiasa waspada terhadap gejalah-gejalah yang merupakan indikasi akan terjadinya masalah dalam pemberian kredit.

Pada hakekatnya, kredit bermasalah terjadi karena tidak terbayarnya kredit yang diberikan oleh Bank BNI 46 yang dapat disebabkan oleh dua faktor yaitu (1) faktor intern Bank (2) faktor ekstern Bank.

Kredit bermasalah tidak timbul secara mendadak, sejak awal, pemberian kredit telah membawa bibit timbulnya kredit bermasalah. Terjadinya kredit bermasalah sering diawali dengan munculnya berbagai indikasi dan gejala (red flag). Gejalah penurunan mutu kredit telah ada sebelum terjadinya kredit bermasalah, Oleh karena itu, Bankir harus mampu mengamati dan mendeteksi secara dini terhadap gejala timbulnya kredit bermasalah sehingga dapat mengambil tindakan pencegahan lebih awal.

Dalam proses pemberian kredit, bank sudah tentu mengawalinya dengan melakukan analisis kredit. Proses ini dimaksudkan untuk meyakinkan bahwa uang Bank nantinya dapat dikembalikan oleh debitur. Proses ini memegang peran yang sangat penting dalam proses pemberian kredit. Pada tahap inilah kelancaran angsuran kredit yang disebabkan oleh kemampuan dan kemauan debitur untuk memenuhi kewajibannya dapat diprediksikan. Oleh karena itu, timbulnya kondosi berupa ketidakmampuan debitur membayar hutang dalam jangka waktu yang ditentukan, dapat diamati pada tahap-tahap awal. Bahkan kesalahan dalam menetapkan kebijakan perkreditan oleh Bank dapat memperbesar risiko terjadinya kredit bermasalah. Sebagai contoh: ekspansi secara besar-besaran karena kelebihan likuiditas, kredit dengan jangka waktu lama, kebijakan agunan, kredit tanpa angsuran dengan jaminan yang ringan, dan sebagainya.

Sehubungan dengan ketentuan undang-undang yang mengatur tentang pelaksanaan pemberian kredit tersebut di atas, maka Bank BNI 46 Polewali mandar dan Bank Perkreditan Rakyat wajib melakukan analisis kredit yang mendalam atas permohonan kredit yang diajukan oleh calon debitur, dan memiliki serta menerapkan pedoman perkreditan dalam melaksanakan perkreditannya.

Teori yang digunakan adalah teori Perjanjian tentang kesepakatan dan teori tentang perbuatan pidana. Teori kesepakatan digunakan di dalam penelitian ini untuk menganalisis permasalahan wanprestasi dalam perjanjian yang telah disepakati oleh para pihak sedangkan teori perbuatan pidana digunakan untuk menganalisis permasalahan tentang delik penipuan dalam perjanjian.

\section{METODE}

Penelitian ini dilakukan pada PT. Bank Negara Indonesia (Persero) Tbk Polewali Mandar . Objek yang diteliti dalam kredit bermasalah tahun 2019-2020. Dipilihnya PT Bank Negara Indonesia 46 Polewali Mandar sebagai objek penelitian karena merupakan salah satu unit bisnis tersendiri diantara sekian unit yang terdapat di BNI dan mengkhususkan pelayanan kredit konsumtif. Posisi outstanding pinjaman yang diberikan kepada debitur, yang terdiri dari pinjaman tidak lancar sehingga layak untuk diketahui bagaimana proses penyelesaiannya. Teknik pengumpulan data dalam penelitian ini adalah dengan cara mempergunakan dua sumber data, yakni:

1. Data Primer, diperoleh dari penelitian langsung terhadap objek penelitian di lapangan dengan cara wawancara yaitu pengumpulan data yang melakukan dengan mewawancarai Responden dan informasi secara langsung.

2. Data Sekunder, diperoleh dari kepustakaan, misalnya dengan mempelajari literatur-literatur serta dokumendokumen resmi yang ada di lapangan yang terkait dengan objek penelitian.

\section{HASIL DAN PEMBAHASAN}

\subsection{Penyelesaian Kredit Bermasalah pada BNI 46 Cabang Polewali Mandar.}

Seperti diketahui yang dimaksud dengan kredit bermasalah atau Non Performing Loans (NPL's) adalah kredit yang diberikan oleh Bank Umum yang memenuhi kriteria kolektibilitas.

Bapak Alqadri Yagub selaku Pimpinan BNI 46 Cabang Polewali Mandar (wawancara 20 Oktober 2020) menyatakan ; kredit bermasalah dengan langkah trakhir yang dapat dilakukan setelah langkah-langkah penyelamatan sebagaimana diatur Surat Edaran Bank Indonesia Nomor 26/4/BPPP Tahun 1993 Tentang Kualitas Aktiva Produksi dan Pembentukan Penyisihan Penghapusan Aktiva Produksi yang berupa restrukturisasi tidak efektif lagi. Karena penyelesaian kredit bermasalah melalui lembaga hukum yang memegang memerlukan waktu yang relative lama dan bila melalui badan peradilan maka kepastian hukumnya baru ada setelah memiliki kekuatan hukum tetap (inkraacht van bewijs). Melalui Panitia Urusan Negara (PUPN) dan Direktorat Jenderal Piutang dan Lelang Negara (DJPLN) berdasarkan pada Undang-Undang Nomor 49 Tahun 1960 Tentang Panitya Urusan Piutang Negara, melalui badan peradilan dan melalui mengefektifkan penagihan piutang Negara. Pernyataan diawali dengan perundingan yang dikeluarkan PUPN dan DJPLN mempunyai kekuatan pelaksanaan seperti putusan hakim yang telah berkekuatan hukum tetap, pelaksanaan dilakukan dengan ketua panitia dengan surat paksa dan melalui cara penyitaan.

Ditegaskan menurut Pasal I angka 11 Undang-Undang Nomor 10 Tahun 1998, merumuskan pengertian kredit ketentuan tersebut seolah-olah Bank juga tidak mementingkan jaminan dalam pencairan kredit. Namun kemudian Pasal 8 Undang-Undang Nomor 10 Tahun 1998 bahwa penerapan 5c 
(character, capacity, capital, collateral, condition of economy) demikian penting bagi Bank untuk mencairkan kredit. Pasal tersebut menegaskan bahwa dalam memberikan kredit atau pembiayaan berdasarkan prinsip syariah. Bank umum wajib mempunyai keyakinan berdasarkan analisis yang mendalam atas itikad baik dan kemampuan serta kesangguban nasabah debitur untuk melunasi utangnya atau mengembaikan

Adapun cara penyelesaian Kredit Bermasalah dengan cara adalah:

\section{a. Penyelesaian Kredit Bermasalah di Luar Proses Pengadilan}

Untuk menyelesaikan Kredit bermasalah adalah dengan 2 cara melakukan Upaya di luar proses Pengadilan, dan dengan proses Pengadilan dengan cara:

1) Penagihan Langsung oleh Bank

Penagihan langsung atas kredit bermasalah dapat dilakukan bilaman Bank mempunyai keyakinan bahwa perusahaan debitur masih dapat berjalan atau berjalan kembali setelah tindakan rescheduling, reconditioning, restructuring atau kombinasi di antara ketiganya. Surat Penagihan resmi yang dikirimkan Bank kepada debitur perlu menegaskan bahwa debitur yang bersangkutan harus melunasi pokok kreditnya beserta bunga tertunggak sebesar jumlah saldo terakhir. Bank juga harus mencatumkan batas waktu terakhir yang wajar kepada debitur untuk melunasi seluruh kewajibannya. Apabila dalam beberapa kali penagihan tidak ada hash atau tidak direspon dengan baik oleh debitur, sebaiknya Bank menghentikan pelayanan kepada debitur, misalnya menghentikan kredit yang belum dicairkan, membekukan rekening tabungan dan lainnya.

Sebagai besar debitur biasanya bersikap baik kepada Bank, walapun mereka telah menerima surat peringatan resmi. Hal ini tersebut sebenarnya membawa banyak manfaat, karena sikap demikian membuka kemungkinan adanya perundingan lebih lanjut antara denitur dengan Bank untuk mencari jalan kelaur atas pemecahan kredit bermasalah yang sedang terjadi. Penyelesaian kredit bermasalah dengan jalan damai seringkali dapat membawah hash yang lebih memuaskan kedua belah pihak adalah Bank mengijinkan debitur menjual sendiri barang jaminan, di mana hasil penjualannya digunakan untuk melunasi kewajibannya debitur.

2) Penagihkan Kredit Kepada Penjamin

Kredit pihak ketiga seperti jaminan perseorangan (personal guarantee), jaminan Perusahaan (coorporate guarante) dan jaminan Bank( Bank gurantee), mereka disebut penagggung atau penjamin (guarantor, co-obligor atau borgtacht). Apabila debitur tidak mampu atau tidak bersedia melunasinya Bank dapat menagihkan kredit tersebut kepada penjamin. Jumlah pinjaman yang dapat ditagihkan kepada penjamin bisa seluruhnya atau sebagaian, bisa berupa kepada penjamin tergantung kewajiban penjamin sebagaimana tercantum dalam perjanjian kredit atau perjanjian penjaminan kredit

3) Bekerja sama dengan Kreditur Lain

Apabila kredit bermasalah biasanya penagihannya dilakukan secara bersama. Debitur menunggak pembayarn
Kredit yang diberikan oleh Bank BNI 46. Para kreditur satu tim secara bersama-sama menyelesaikan kredit yang bermasalah. Dalam pelaksanaan penagihan kreditur melakukan negosisasi dengan debitur. Secara berkala trustee melaporkan perkembangan upaya penyelesaian kredit bermasalah kepada para anggota sindikasi dan membagi hasilnya secara pari pasu atau proporsional yaitu sesuai dengan perbandingan jumlah kredit bermasalah masingmasing kreditur.

Manfaat yang diperoleh para kreditur menyelesaikan kredit bermasalah secara bersama-sama adalah memperkuat posisi tawar-menawar dihadapan debitur, dan juga dapat mengurangi biaya penanganan kredit bermasalah, dibanfgkan bilamana mereka melakukannya sendiri-sendiri

4) Penagihan Oleh Penagih Utang

Dalam rangka mempercepat penyelesaian penagihan kredit bermasalah, pihak bank dapat memanfaatkan jasa penagih utang yang lazim disebut dengan debt collector. Dalam banyak kasus penagihan oleh debt collector lebih efektif dibandingkan dengan cara menyerahkannya kepada PUPN atau melalui proses gugatan perdata di Pengadilan, karena pihak Bank cukup memerintahkan pihak penagih utang berdasarkan surat kuasa untuk dan atas nama Bank menagih utang kepada debitur bermasalah.

Kebanyakan Bank swasta menggunakan debt collector untuk menagih kredit dan debitur bermaslah, hal ini antara lain disebabkan proses penegakan hukum tidak menjamin kepastian hukum dan debt collector dianggap lebih mampu bekerja dalam waktu relatif singkat dengan tingkat keberhasilan cukup tinggi.

Pasal 1 angka 22 hurup C Undang-Undang No.7 Tahun 1992 Tentang Perbankan sebagaimana telah diubah oleh Undang-Undang No.10 Tahun 1998 menetapkan bahwa pihak terafiliasi adalah "pihak yang memberikan jasanya kepada Bank, antara lain akuntan publik, penilai, konsultan hukum dan konsultan lainnya".

5) Pemanggilan dengan Iklan Panggilan

Cara lain menagih kredit dan debitur bermasalah adalah dengan memasang iklan panggilan pada media masa, terutama surat kabar. Dalam iklan tersebut biasanya disebutkan nama jelas dan alamat debitur, himbauan kepada debitur agar dalam batas waktu tertentu untuk datang ke kantor Bank guna menyelsaikan kewajiban keuangannya, disertai dengan ancaman bilamana debitur tidak memenuhi panggilan Bank akan mengambil tindakan hukum.

Ada kemungkinan dengan cara penagihan seperti itu akan berhasil, debitur yang takut diajukan ke pengadilan akan datang dan berusaha melunasi utangnya. Upaya ini juga merupakan suatu shock terapy bagi para debitur bermasalah lain yang belum diiklankan, dengan adanya pengiklanan ini debitur lain akan segera datang kepada Bank untuk menyelesaikan utangnya. Akan tetapi, pemanggilan debitur melalui pemasangan iklan mengandung risiko bagi Bank, antara lain: 
a. Debitur bermasalah yang dipampangkan diiklan, merasa nama baiknya dicemarkan dan mengajukan gugatan maka di samping tagihan Bank kepada yang bersangkutan belum terselesaikan. Bank akan menghadapi masalah baru, yakni menghadapi gugatan debitur di pengadilan;

b. Jika debitur bermasalah yang dipampangkan dalam iklan tersebut jumlahnya banyak, ada kemungkinan mereka bersama-sama menggugat Bank.

c. Kemungkinan Bank yang bersangkutan ditakuti oleh para calon debitur, sehingga sedikit banyak akan mempengaruhi kinerja pemasaran produk-produk kredit Bank. Hal ini juga dapat mempengaruhi peluang penghimpunan dana, karena ada kemungkinan para calon debitur memilih Bank lain untuk meminjam dan menyimpan uangnya.

6) Penyelesaian Kredit Bermasalah Melalui Badan Arbitrase

Dalam perjanjian kredit dimungkinan mencatumkan klausula penyelesaian sengketa antara pihak Bank dengan debitur melalui arbitrase. Dalam klausula arbitrase menetapkan cara-cara penunjukan arbiter dan susunan yang akan memutuskan perkara. Tim arbiter dibentuk dengan masing-masing pihak menunjuk seorang arbiter dan kemudian kedua arbiter memilih seorang arbiter lain sebagai ketua tim arbiterase. Manfaat penyelesaian segketa melalui arbitrase adalah keputusannya bersifat final. Prosesnya tertutup sehingga bisa menjaga nama baik para pihak yang bersengketa dan lebih cepat bila dibandingkan dengan melalui pengadilan.

Saat ini di Indonesia telah berdiri dua badan arbitrase, yakni Badan Arbitrase Nasional Indonesia (BANI) dan Badan Arbitrase Muamalat Indonesia (BAMUI). BANI didirikan oleh Kamar Dagang dan Industri Indonesia (KADIN) pada tanggal 3 Desember 1977, dengan tujuan memberikan penyelesaian yang adil dan cepat dalam sengketa-sengketa perdata yang timbul mengenai soal-soal perdagangan, industri dan keuangan, baik yang bersifat nasional maupun Nasioanal.

7) Penyerahan Pengurusan Kredit Macet Kepada PUPN

Dengan ditetapkannya Undang - Undang No.49/Prp/Tahun 1960 Tentang Panitia Urusan Piutang Negara, maka dibentuklah Panitia Urusan Piutang Negara (PUPN) melalui Keputusan Menteri Keuangan No. 294/KMK.09/1993 Tentang Panitia Urusan Piutang Negara. Di antara tugasnya adalah mengurus piutang negara yang oleh pemerintah atau badan-badan yang secara langsung atau tidak langsung dikuasai oleh Negara berdasarkan suatu peraturan, perjanjian atau sebab lainnya telah diserahkan pengurusannya kepada PUPN.

Hal-hal lain yang diatur oleh peraturan Perundangundangan tersebut, bahwa:

a. Instansi pemerintah dan badan-badan Negara diwajibkan menyerahkan kepada PUPN pengurusan piutangpiutangnya yang adanya dan besarnya telah pasti menurut hukum akan tetapi penanggung utang tidak mau melunasi sebagaimana mestinya/ lain halnya dengan Bank-Bank milik swasta, Bank-Bank milik Negara dan daerah dilarang menyerahkan pengurusan piutangnya atau kredit macetnya kepada pengacara.

b. Untuk memperoleh kepastian adanya dan besarnya piutang yang wajib diselesaikan oleh Penanggung utang serta syarat-syarat penyelesainnya, PUPN melakukan perundingan dengan penaggung utang.

c. Pernyataan bersama antara PUPN dan penanggung Utang, berkepala/berjudul eksekutorial berbunyi "Atas Nama Keadilan". Oleh karena itu, surat pernyataan bersama tersebut merupakan pernyataan pengukuhan uatang yang mempunyai kekuatan pembuktian yang sempurnah (volledeg bewijs) dan kekuatan memaksa (dwingend bewijs).

d. Dalam hal penaggung utang tidak kooperatif, misalnya tidak memenuhi panggilan atau menolak mendatangani pernyataan bersama tanpa alasan yang sah, maka PUPN berwenang menetapkan jumlah piutang negara yang wajib dilunasi oleh penanggung utang.

e. Piutang yang telah jatuh tempo tetapi belum dinyatakan macet, pada tingkat pertama pengurusannya diselesaikan oleh instansi pemerintah/badan negara/ badan usaha yang bersangkutan sampai piutang tersebut menjadi kategori macet.

f. PUPN dapat bertindak sendiri tanpa menunggu penyerahan pengurusan piutang, negara, dengan syarat piutang tersebut dikhawatirkan akan merugikan negara.

g. Jika batas waktu pelunasan yang terdapat dalam pernyataan bersama telah terlampaui dan penanggung utang belum menyelesaikan kewajibannya, PUPN dapat mengeluarkan surat paksa sehingga pernyataan dan pelelangan atas kekayaan penanggung utang dapat dilaksanakan. Bahkan PUPN dapat melakukan penyanderaan (gijzeling) atau paksa badan (lijfsdwang) terhadap di penanggung utang. Penyanderaan atau paksa badan dapat dilakukan dengan terlebih dahulu memperoleh persetujuan dan ketua PUPN Pusat, dan hanya dapat dilakukan apabila jumlah utang minimum Rp. 500.000.000,00 serta hash pengusutan PUPN menunjukkan bahwa penanggung utang mempunyai kemampuan untuk membayar utangnya tetapi tidak memperlihatkan itikad baik untuk menyelesaiakan kewajibannya.

h. Untuk pengamanan dan kelancaran pelaksanaan pengurusan piutang negara, penanggung utang dapat dicegah untuk bepergian ke luar negeri sesuai dengan ketentuan yang berlaku.

i. Bank-bank pemerintah yang telah menyerahkan pengurusan piutangnya ke PUPN dapat menarik kembali dengan tujuan untuk menyehatkan usaha penanggung utang yang masih memiliki prospek yang baik dan kemampuan pengembangan usaha di waktu yang akan datang. Penarikan kembali hanya dapat dilakukan satu 
kali untuk setiap kasus piutang negara dengan melampirkan rencana penyehatan yang memuat yang bersangkutan untuk menyelesaikan kewajibannya.

Akan tetapi tindakan-tindakan PUPN tersebut di atas tidak kebal hukum, pihak penanggung utang yang merasa dirugikan dapat mengajukan gugatan ke Pengadilan Negeri atau Pengadilan Tata Usaha Negara yang bisa berakibat tindakan yang sedang dilakukan oleh PUPN dapat dihentikan atau jika telah terlanjur dilakukan dapat dibatalkan.

\section{b. Penyelesaian Kredit Bermasalah Melalui Proses Pengadilan}

Sejalan dengan klausula yang baisanya tercantum dalam perjanjian kredit anatara Bank dengan debiturnya. Maka dalam hal debitur tidak dapat memenuhi kewajibannya untuk melunasi kredit, Bank dapat mengajukan gugatan perdata ke Pengadilan Negeri dan Bank dapat meminta bantuan Pengadilan Negeri untuk melakukam sita eksekusi terhadap harta jaminan debitur yang telah diikat secara sempurna.

Karena debitur tidak memenuhi kewajibannya sesuai perjanjian (wanprestasi) sehingga kreditnya menjadi bermasalah, maka dalam keadaan demikian Bank sebagai kreditur dapat mengajukan gugatan ke Pengadilan Negeri. Pengadilan Negeri akan memproses gugatan tersebut dengan mempertimbangkan bukti-bukti yang diajukan pihak penggugat dan tergugat. Kemudian Ketua Pengadilan Negeri mengirimkan surat peringatan (somasi) kepada debitur atas permintaan Bank, bilamana debitur tidak mengindahkan somasi, Bank meminta Pengadilan Negeri melakukan sita harta jaminan atau conservatoir beslag (CB). Selanjutnya Pengadilan Negeri melakukan panggilan atau teguran (aanmaning) kepada debitur untuk dalam jangka waktu untuk melunasi utangnya. Apabila debitur tidak mengindahkan teguran tersebut, Ketua Pengadilan Negeri akan mengeluarkan surat perintah kepada juru sita Pengadilan Negeri untuk menjual harta jaminan melalui kantor lelang Negara. Hasil lelang harta jaminan diserahkan melalui Pengadilan Negeri kepada Bank Kreditur untuk melunasi kredit debitur dan apabila terdapat sisa akan dikembalikan kepada debitur.

Penyelesaian kredit bermasalah melalui gugatan perdata ke pengadilan kurang menguntangkan, terutama karena waktu yang dibutuhkan relatif panjang. Kenyataan juga menunjukkan bahwa kebanyakan debitur yang dikalahkan pada Penagdilan Tingkat Pertama, mengajukan banding ke Penagdilan Tinggi kasasi ke Mahkamah Agung bahkan melakukan upaya Peninjauan kembali.

\section{KESIMPULAN DAN SARAN}

Hasil penelitian dan pembahasan dapat disimpulkan bahwa pengawasan yang dilakukan OJK belum efektif, tidak mampu mengalami peningkatan jika hanya mengandalkan pola pemantauan dan kontrol pengawasan melalui sistem yang terintegrasi, diperlukan tenaga profesional yang berintegritas untuk secara berkala melakukan pemeriksaan langsung sesuai yang diatur dalam Undang-Undang Otoritas Jasa Keuangan Nomor 21 tahun 2011 Pasal 7, dalam upaya memberikan edukasi keuangan dan pemahaman resiko agar memberi dampak yang baik terhadap kegiatan usaha perbankan.

Faktor penghambat dalam melakukan pengawasan aktivitas perbankan antara lain terbatasnya jumlah sumber daya manusia yang handal dalam bidang pemeriksaan langsung lembaga keuangan perbankan, pengembangan kualitas sumber daya manusia dalam bentuk pelatihan itu dilakukan secara kolektif dan nasional dan infrasturktur data dari lembaga pengawas sebelumnya ada namun tidak dapat diandalkan oleh OJK.

\section{DAFTAR PUSTAKA}

Rachmadi Usman, 2001, Aspek-Aspek Hukum Perbankan Di Indonesia, Gramedia, Jakarta.

Siswanto Sutojo, 1997, Analisis Kredit Bank Umum, Pustaka Binaman Pressindo, J

Yunus Husein, 1994, Kelembagaan Usaha dan Pengelolahan Bank, makalah ini disampaikan dalam Temu ilmiah Perbankan dan Sistem Keuangan.

Kitab Undang Undang Hukum Perdata

Undang-undang No 4 tahun 1996 tentang Hak tanggungan atas Tanah beserta benda- benda yang berkaitan dengan tanah.

Undang-undang nomor 42 Tahun 1999 Tentang Jaminan Fiducia.

Undang-undang No 10 tahun 1998 tentang perbankan.

Bank Indonesia (A), Surat Keputusan Direksi Bank Indonesia Tentang Kualitas Aktiva Produktif, SK No. 30/267/KEP/DIR/1998, psl. 4.

Bank Indonesia (A), Surat Keputusan Direksi Bank Indonesia Tentang Kualitas Aktiva Produktif, SK No. 30/267/KEP/DIR/1998, psl. 4.pasal 2.

Bank Indonesia (B), Peraturan Bank Indonesia Tentang Penilaian Kualitas Aktiva Bank Umum, PBI No. 7/2/PBI/2005, LN No. 12 DPNP Tahun 2005, TLN No. 4471

Bank Indonesia, Pedoman Penyusunan Kebijaksanaan Perkreditan Bank (PPKPB), Lampiran SK DIR BI No. 27/162/DIR

Indonesia (B), Undang-Undang tentang Perbankan Sebagaimana telah diubah dengan Undang-Undang Republik Indonesia Nomor 10 Tahun 1998, UU No. 7 Tahun 1992, LN No. 182 Tahun 1998, TLN No. 3790

Indonesia(C), Undang-Undang Tentang Perubahan atas Undang-Undang No. 7 Tahun 1992 Tentang Perbankan, UU No. 10 Tahun 1998, LN No. 182

Tahun 1998, TLN No. 3790 , pasal 37 ayat 1 huruf c. 